\title{
Nest temperature fluctuations in a cavity nester, the southern ground-hornbill
}

\author{
L. Combrink ${ }^{a, b}$, H.J. Combrink ${ }^{c}$, A.J. Botha ${ }^{b}$, C.T. Downs ${ }^{a}{ }^{*}$ \\ ${ }^{a}$ School of Life Sciences, University of KwaZulu-Natal, P/Bag X01, Scottsville, Pietermaritzburg 3209, South \\ Africa \\ ${ }^{b}$ The Endangered Wildlife Trust, P/Bag X11, Modderfontein, Johannesburg 1645, South Africa \\ ' Department of Veterinary Tropical Diseases, University of Pretoria, P/Bag X04, Onderstepoort, Pretoria 0110, \\ South Africa \\ *Corresponding author. \\ E-mail addresses: downs@ukzn.ac.za, leighc@ewt.org.za (C.T. Downs).
}

\section{Highlights}

- The endangered southern ground-hornbill nests in the austral summer.

- They are secondary cavity nesters, but use artificial nest boxes.

-We investigated their nest cavity and ambient temperatures concurrently.

- Nest temperatures varied between nests, with natural nests providing a buffer against ambient temperature fluctuations..

- Cavity nest temperature had no influence on breeding success.

\section{Abstract}

Southern ground-hornbills Bucorvus leadbeateri inhabit savanna and bushveld regions of South Africa. They nest in the austral summer, which coincides with the wet season and hottest daytime temperatures in the region. They are secondary cavity nesters and typically nest in large cavities in trees, cliffs and earth banks, but readily use artificial nest boxes. Southern ground-hornbills are listed as Endangered in South Africa, with reintroductions into suitable areas highlighted as a viable conservation intervention for the species. Nest microclimate, and the possible implications this may have for the breeding biology of southern ground-hornbills, have never been investigated. We used temperature dataloggers to record nest cavity temperature and ambient temperature for one artificial and 11 natural southern ground-hornbill tree cavity nests combined, spanning two breeding seasons. Mean hourly nest temperature, as well as mean minimum and mean maximum nest temperature, differed significantly between southern ground-hornbill nests in both breeding seasons. Mean nest temperature also differed significantly from mean ambient temperature for both seasons. Natural nest cavities provided a buffer against the ambient temperature fluctuations. The artificial nest provided little insulation against temperature extremes, being warmer and cooler than the maximum and minimum local ambient temperatures, respectively. Nest cavity temperature was not found to have an influence on the breeding success of the southern ground-hornbill groups investigated in this study. These results have potentially important implications for southern ground-hornbill conservation and artificial 
nest design, as they suggest that the birds can tolerate greater nest cavity temperature extremes than previously thought.

\section{Keywords}

Cavity nester; Temperature fluctuation; Nest temperature; Hornbill; Conservation

\section{Introduction}

The choice of a nest site can have a profound influence on energy expenditure during incubation, which in turn, can affect overall breeding success (D'Alba et al., 2009; Heenan, 2013; Hilton et al., 2004 ; Reid et al., 2000). Birds that do not construct their own nests, such as secondary cavity nesters, are often limited by the availability of suitable nesting sites (Cockle et al., 2010 ; Newton, 1994). When suitable nests are limiting, stronger or fitter individuals will often occupy the best nests enhancing their reproductive output (Robertson and Rendell, 1990).

During incubation, birds need to partition their energy resources to conserve body condition for future reproduction, as well as ensure that sufficient energy is allocated to the current breeding attempt (Heenan, 2013 ; Reid et al., 2000). Egg temperatures should be kept fairly constant to ensure optimal growth during incubation (DuRant et al., 2013; Hart et al., 2016 ; Kemp and Monaghan, 2006). Tropical birds tend to expend less energy keeping their eggs at suitable temperatures owing to the prevailing climatic conditions (Hart et al., 2016). Even so, the amount of exposure to the elements that a nest receives could also influence breeding success (Hart et al., 2016).

An ideal nest site is one that offers shelter from direct sunlight and wind, and that provides some measure of insulation (DuRant et al., 2013). Cavity-nesters are somewhat buffered from the elements in this respect (Cooper, 1999 ; Martin and Ghalambor, 1999) and much work has been done studying the microclimates of, in particular, tree cavities used for nesting (Hooge et al., 1999; Wiebe, 2001 ; Maziarz et al., 2017), roosting (Cooper, 1999) and hibernating (Coombs et al., 2010).

In birds, nest microclimate or thermal environment has been shown to affect clutch size (Wiebe, 2001) and breeding success (Deeming et al., 2012; Kemp and Monaghan, 2006 ; Reid et al., 2000). Nest construction and location can have a profound effect on nest microclimates (DuRant et al., 2013 ; Wiebe, 2001), with nest insulation thought to be a critical feature of nest construction in many bird species (Deeming et al., 2012). Differences in insulation between natural cavity nests and artificial nest boxes are poorly documented, despite the role that this may play in nest site selection by birds (Maziarz et al., 2017). Most studies have shown that nest boxes are less insulated than natural tree cavities and, owing to their uniform design, would thereby provide limited variation in the quality of nest sites available for secondary cavity nesters (Maziarz et al., 2017). Ellis (2016) showed that nest boxes had similar microclimates irrespective of the size and shape of the design and 
suggested that placement and construction material of the nest box were far more important factors in determining nest microclimate. The quality of a particular nest site (Wiebe, 2001) and factors like climate change (Matthysen et al., 2011) would directly affect the nest microclimate and could influence incubation temperatures. This could then increase the selective pressures exerted on incubating adults to maintain optimal nest thermal conditions (DuRant et al., 2013).

Finding a suitable nest site to optimise incubation conditions can be especially challenging for large secondary cavity nesting birds that are territorial, such as the southern groundhornbill Bucorvus leadbeateri. Southern ground-hornbills breed during the austral summer, from October to March each year, which coincides with the first annual rains in the South African Lowveld (Kemp, 1995). They typically nest in tree cavities, rock crevices and earth banks, but take readily to artificial nesting sites. The species has suffered a significant decline in South Africa owing mainly to habitat loss and persecution (Kemp and Webster, 2008) and is listed nationally as Endangered ( Taylor et al., 2015) and globally as Vulnerable ( IUCN, 2016). A National Species Recovery Plan was developed in an effort to curtail this decline, with reintroductions of the birds into suitable habitat being listed as one of the primary conservation goals for South Africa (Jordan, 2011). The erection of artificial nests at these sites will increase the availability of suitably-sized nest sites. It is paramount that these artificial nests offer the best conditions for nesting to ensure the persistence and longterm survival of the birds, as well as to optimise their breeding success at reintroduction sites.

We investigated the thermal fluctuations of southern ground-hornbill nest cavities during the breeding season to determine the current range of temperatures experienced by these birds. We predicted that their cavity nests would have more stable temperatures than the associated diel ambient temperatures. We also related their nesting success to cavity nest and ambient temperature maximums and minimums to see if these had any effect on overall reproductive output. We predicted that their nests in anthropogenic structures would have higher temperatures and experience greater extremes of temperatures than natural cavity nests in hollows of trees.

\section{Methods}

\subsection{Study area}

We conducted the study in Kruger National Park (KNP) and associated conservation areas, South Africa $\left(22-26^{\circ} \mathrm{S}, 30-32^{\circ} \mathrm{E}\right)$ in an area known as the South African Lowveld. The area is diverse, but has an average annual rainfall of 350-750 mm (Gertenbach, 1980), and consists mainly of savanna, with pockets of dense woody vegetation within broader grasslands (Gertenbach, 1983). 


\subsection{Nest temperatures}

We recorded southern ground-hornbill nest temperatures and associated ambient temperatures during two breeding seasons (2013-2014, 2014-2015) with calibrated data logger i-Buttons ${ }^{\circledR}$ (Model DS $1922 \mathrm{~L} \pm 0.06^{\circ} \mathrm{C}$, Dallas Semiconductor, Sunnyvale, CA) in natural nests in KNP and one artificial nest in an associated conservation area (Fig. 1). All iButtons ${ }^{\circledR}$ were calibrated with mercury thermometers $\left(0.05^{\circ} \mathrm{C}\right)$ in a water bath at temperatures from 5 to $45^{\circ} \mathrm{C}$. i-Buttons ${ }^{\circledR}$ were programmed to take a temperature reading every $15 \mathrm{~min}$.

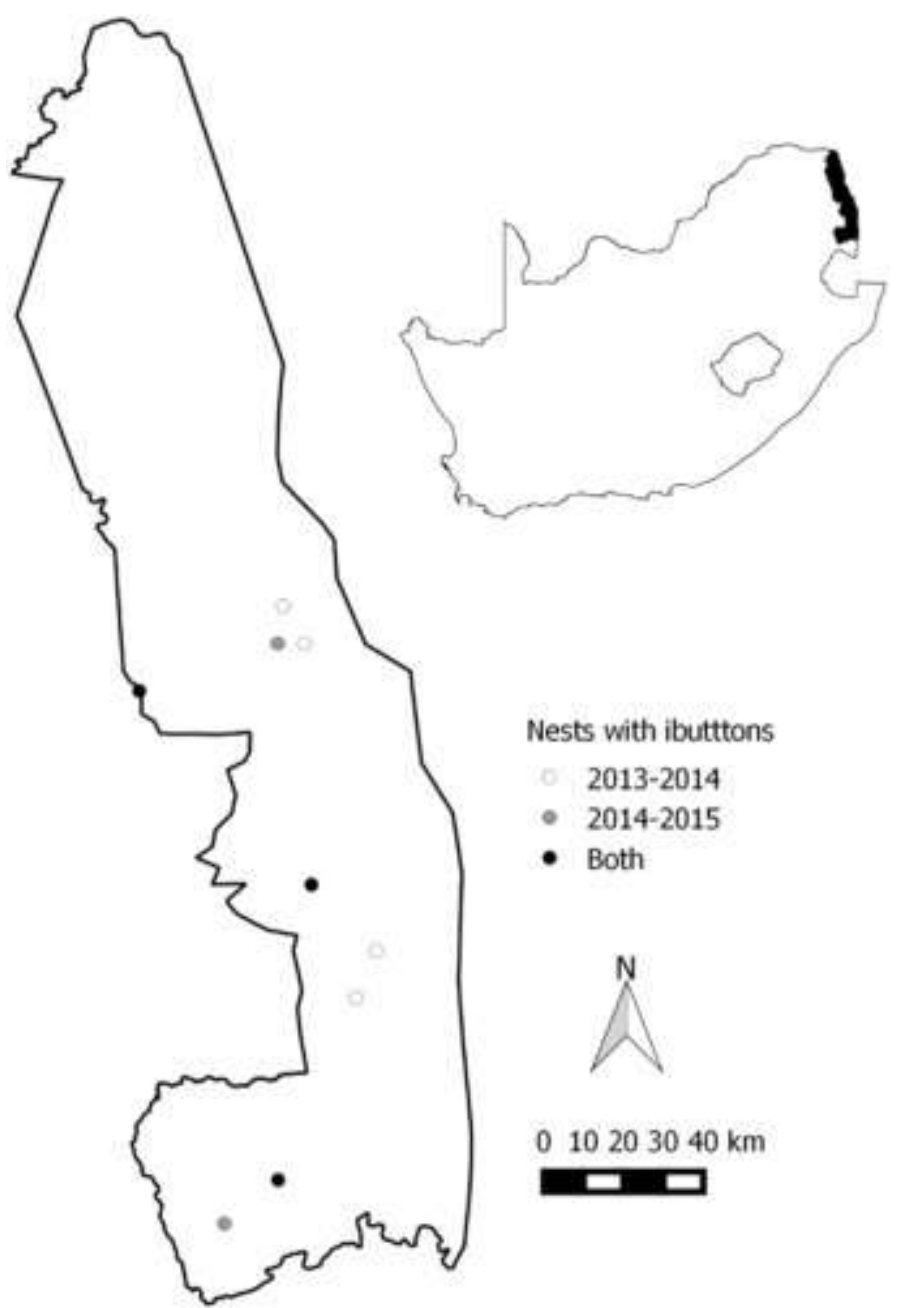

Fig. 1. The locations of southern ground-hornbills nest sites sampled within the Kruger National Park and associated conservation areas, South Africa.

For nest cavity temperatures, i-Buttons ${ }^{\circledR}$ were secured on the inside wall of the nest cavities, just underneath the layer of nesting material, with epoxy glue. Suitable locations outside the nest cavity, but out of direct sunlight, were sought to secure i-Buttons ${ }^{\circledR}$ (again with epoxy glue) to record ambient temperature. Initially, nine natural southern groundhornbill nests were selected, but owing to the loss of i-Buttons ${ }^{\circledR}$ during the 2013-2014 breeding season, nest and ambient temperature data were only collected from six natural nest sites. In the 2014-2015 breeding season, we were again unable to recover all of the i- 
Buttons ${ }^{\circledR}$ and nest temperature data were only collected for four natural southern groundhornbill nests, with ambient temperature data only collected from three natural nests. There was only one artificial nest available within the study area. i-Buttons ${ }^{\circledR}$ were deployed at the artificial nest site to record both ambient and nest cavity temperature in both the 2013-2014 and 2014-2015 breeding season. Although a total of 20 i-Buttons ${ }^{\circledR}$ were deployed throughout this study, only 10 were recovered (many only as a result of using a metal detector) owing to the birds discovering them and actively pecking them off from the nest cavity's walls. Nest activity and success for each breeding season were also recorded.

\subsection{Statistical analyses}

Initially, we calculated hourly mean temperatures for each day in each month. We then determined the daily minimum and maximum hourly mean nest temperature for each month. We performed Analysis of Variance (ANOVA) and Repeated Measures Analysis of Variance (RMANOVA) to determine whether there was a significant difference in southern ground-hornbill nest temperatures. Data from both active and inactive nests for the 20132014 breeding season were pooled for the RMANOVA analyses, as Post-hoc Scheffe tests showed that this was not a dividing factor. We used Tukey Post-hoc tests to determine among which sites significant differences in temperatures occurred. The above statistics were performed using the Statistica 7 package (Statsoft Inc., Tulsa, OK, USA). All graphs were plotted using the ggplot2 (Wickham, 2009) and cowplot (Wilke, 2016) packages in R (Version 3.2.2; R Core Team, 2016).

A generalised linear mixed model with a binomial distribution and logit link function was applied using the $\mathrm{R}$ Ime4 package (Bates et al., 2015) to determine if either nest or ambient minimum and maximum temperatures had any effect on nesting success. Nest success was the response variable and Nest and Year were included as random effects. A nest was considered successful if the nestling reached ringing age (60-70 days).

\section{Results}

\subsection{Nest characteristics and success}

The measurements and characteristics of the various southern ground-hornbill cavity nest sites are included in Table 1, with data on the activity and success of each nesting attempt presented in Table 2. None of the nest characteristics were shown to have an effect on nesting success for southern ground-hornbills in the Kruger National Park (Combrink, unpubl. data). We tested the effect of maximum and minimum nest cavity and ambient temperatures on nest success and found no significant impact [Nest success: nest maximum temperature $(P=0.311)$, nest minimum temperature $(P=0.168)$, ambient maximum temperature $(P=0.267)$, ambient minimum temperature $(P=0.250)]$. 
Table 1. Characteristics of the southern ground-hornbill nests included in this study.

\begin{tabular}{|c|c|c|c|c|c|}
\hline \multirow[b]{2}{*}{ Nest } & \multicolumn{2}{|c|}{ Tree measurements } & \multicolumn{3}{|c|}{ Nest cavity measurements } \\
\hline & Tree species & $\begin{array}{l}\text { Diameter at breast } \\
\text { height }(\mathrm{cm})\end{array}$ & $\begin{array}{l}\text { Diameter base } \\
\text { (I) }(\mathrm{cm})\end{array}$ & $\begin{array}{l}\text { Diameter base } \\
\text { (b) }(\mathrm{cm})\end{array}$ & $\begin{array}{c}\text { Depth (lip to } \\
\text { base) }(\mathrm{cm})\end{array}$ \\
\hline Hlahlene & $\begin{array}{l}\text { Diospyros } \\
\text { mespiliformis }\end{array}$ & 127 & 42 & 53 & 65 \\
\hline Jock & $\begin{array}{l}\text { Diospyros } \\
\text { mespiliformis }\end{array}$ & 151 & 60 & 35 & 36 \\
\hline Mangake & $\begin{array}{l}\text { Diospyros } \\
\text { mespiliformis }\end{array}$ & 65 & 55 & 40 & 40 \\
\hline Mpfuleni & Ficus sycomorus & 127 & 35 & 45 & 50 \\
\hline Mudzadzene & $\begin{array}{l}\text { Combretum } \\
\text { imberbe }\end{array}$ & 83 & 55 & 49 & 79 \\
\hline Nhlanganini & $\begin{array}{l}\text { Philenoptera } \\
\text { violacea }\end{array}$ & 95 & 37 & 45 & 38 \\
\hline Nwaswitsontso & $\begin{array}{l}\text { Diospyros } \\
\text { mespiliformis }\end{array}$ & 141 & 66 & 28 & 29 \\
\hline Oorlas & $\begin{array}{l}\text { Philenoptera } \\
\text { violacea }\end{array}$ & 99 & 45 & 45 & 50 \\
\hline PMC & Artificial & NA & 57.2 & 57.2 & 52.5 \\
\hline
\end{tabular}

Table 2. Activity and nesting success of southern ground-hornbill nests included in this study.

\begin{tabular}{|c|c|c|c|c|}
\hline \multirow{2}{*}{ Nest } & \multicolumn{2}{|c|}{ 2013-2014 season } & \multicolumn{2}{|c|}{ 2014-2015 season } \\
\hline & Active & Successful & Active & Successful \\
\hline Hlahlene & Yes & No & - & - \\
\hline Jock & Yes & Yes & Yes & Yes \\
\hline Mangake & - & - & Yes & Yes \\
\hline Mpfuleni & No & No & - & - \\
\hline Mudzadzene & Yes & Yes & Yes & Yes \\
\hline Nhlanganini & - & - & Yes & Yes \\
\hline Nwaswitsontso & No & No & - & - \\
\hline Oorlas & No & No & - & - \\
\hline PMC & Yes & Yes & Yes & Yes \\
\hline
\end{tabular}

\subsection{Nest temperatures}

The mean hourly temperature showed that most southern ground-hornbill nest cavity temperatures fluctuated daily (Fig. 2) with the artificial nest (PMC) showing the greatest fluctuation. The temperature ranges recorded for both ambient and nest cavity temperatures are presented in Table 3. The mean hourly nest temperature differed significantly between the southern ground-hornbill nests across both seasons (2013-2014: $\left.F_{(6,468)}=53.879 ; 2014-2015: F_{(4,324)}=35.25 ; P<0.05\right)$. In addition mean hourly nest temperature differed significantly from mean hourly ambient temperature for both seasons 
(Figs. 3a and 4a), with ambient temperature being below nest temperature for all nests excepting Mpfuleni in the 2013-2014 breeding season.
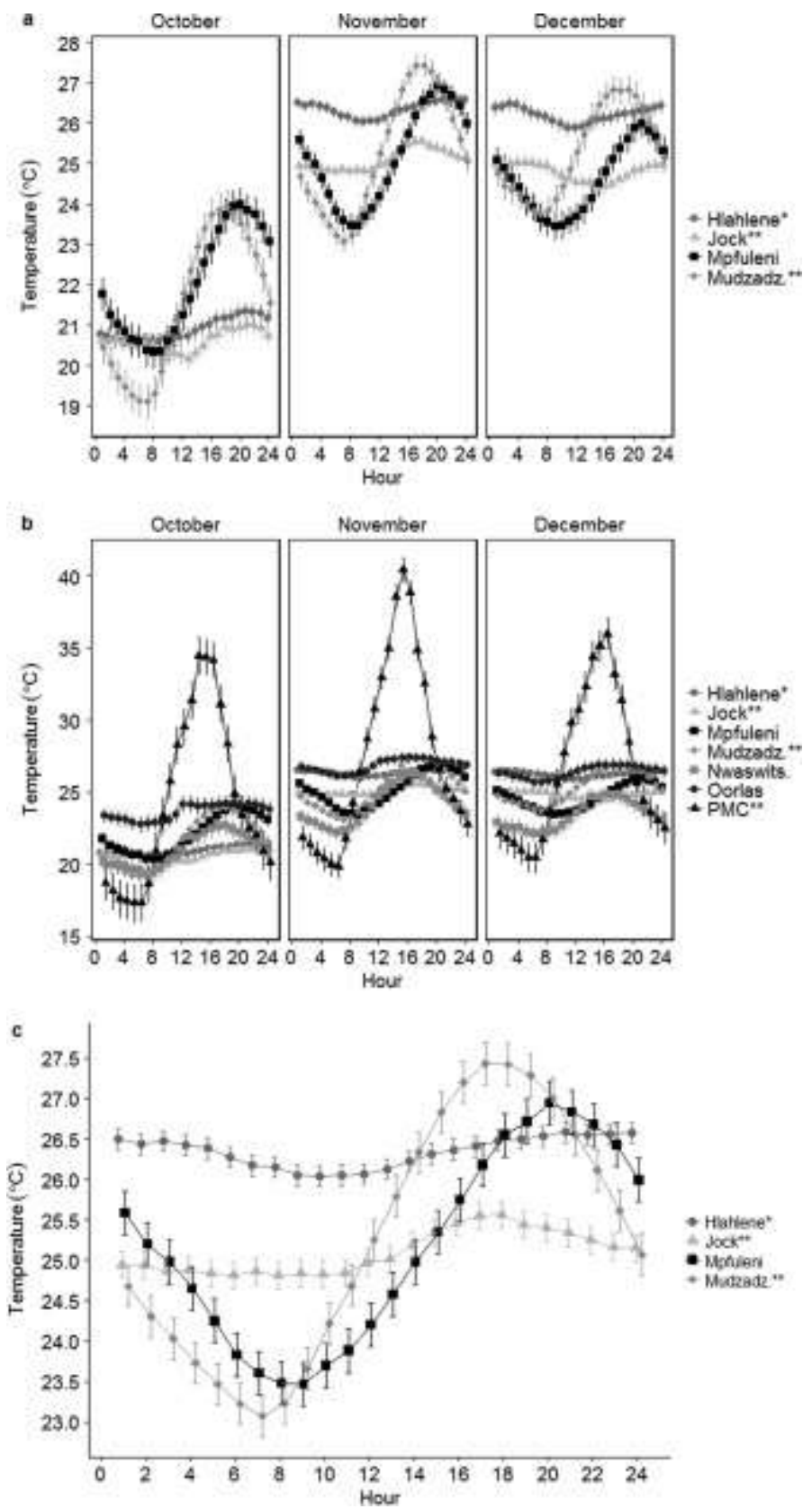

Fig. 2. Mean (+SE) hourly nest temperature of a range of southern ground-hornbills nest cavities in the Kruger National Park and associated conservation areas, South Africa, in the 2013-2014 breeding season where a. shows the fluctuations in some natural cavities, b. shows all the nests including the artificial one (PMC) for the duration of study period in the breeding season $\left(F_{(6,468)}=53.879, p<0.05\right)$, and $c$. the mean hourly fluctuations for some of the nests during December 2013 in the breeding season. (Note: * indicates an active but unsuccessful nest, ${ }^{* *}$ is an active and successful nest, no markings indicate inactive nests. 

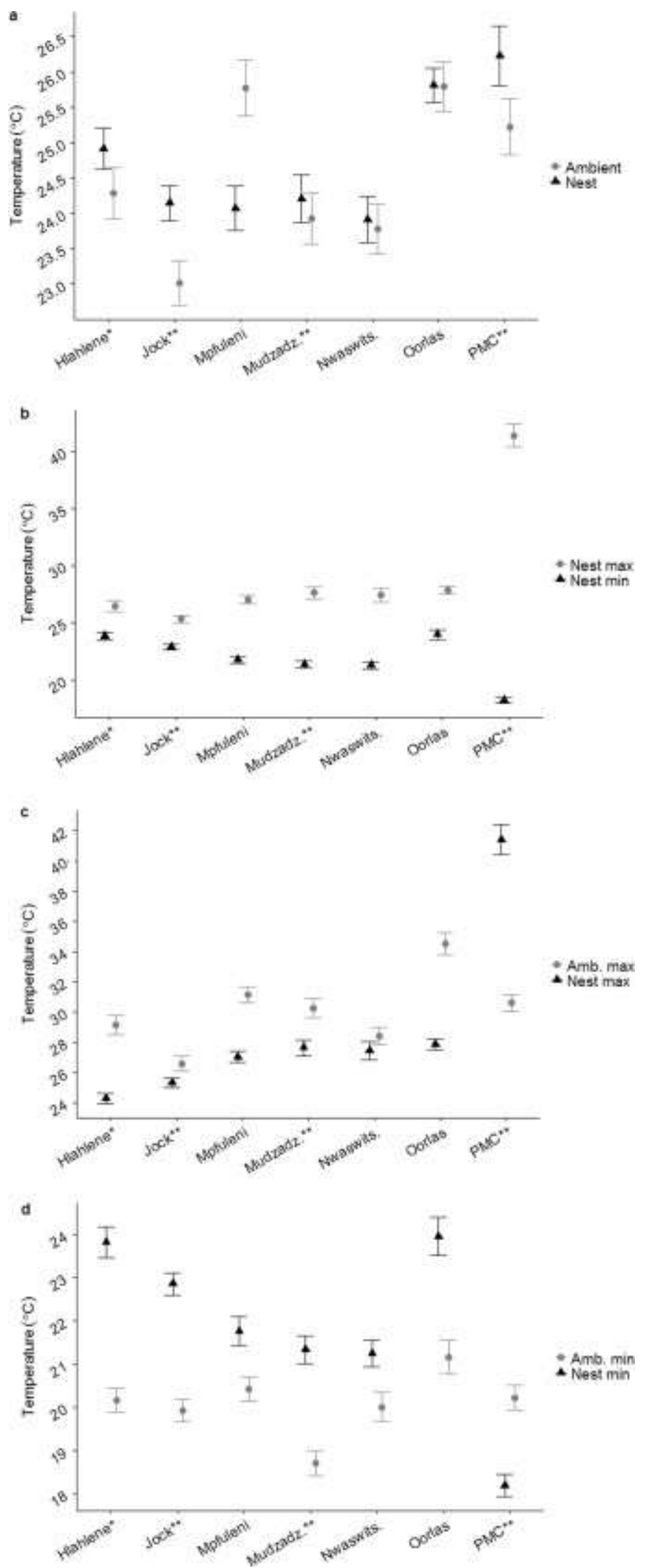

Fig. 3. Comparison of southern ground-hornbill nest temperatures in the 2013-2014 breeding season where a. is mean hourly temperature of each nest versus mean hourly ambient temperature for each nest $\left(F_{(6,}\right.$, $\left.{ }_{468)}=53.879, p<0.05\right)$, b. is mean minimum temperature versus mean maximum temperature of each nest $\left(F_{(6}\right.$, $\left.{ }_{468)}=223.11, p<0.05\right)$, $c$. is nest maximum temperature versus ambient maximum temperature for each nest $\left(F_{(6}\right.$, $\left.{ }_{468)}=199.02, p<0.05\right)$, and $d$. is nest minimum temperature versus ambient minimum temperature for each nest $\left(F_{(6,468)}=173.93, p<0.05\right)$. (Note: All values are mean $+S E . *$ indicates an active but unsuccessful nest, $* *$ is an active and successful nest, no markings indicate inactive nests.).

8 

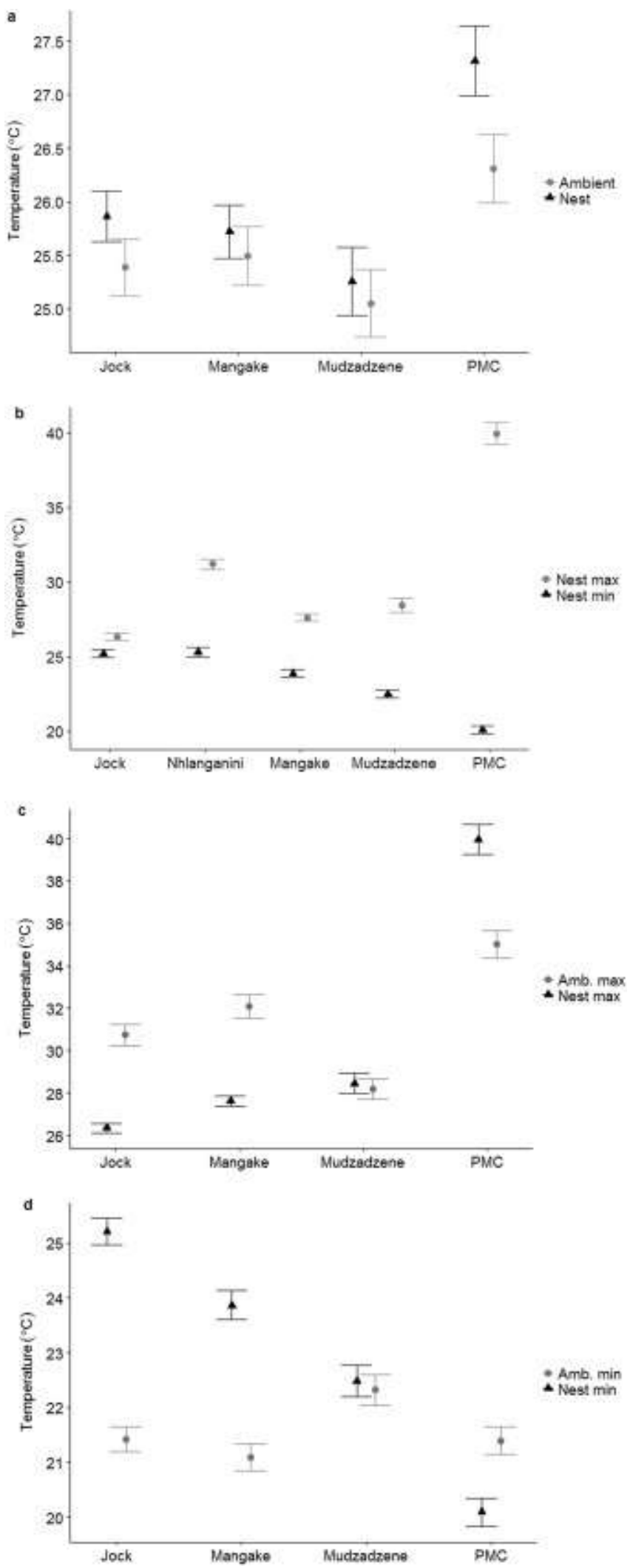

Fig. 4. Comparison of southern ground-hornbill nest temperatures in the 2014-2015 breeding season where a. is mean hourly temperature of each nest versus mean hourly ambient temperature for each nest $\left(F_{(3,}\right.$, $\left.{ }_{255)}=8.352, p<0.05\right), b$. is mean minimum temperature versus mean maximum temperature of each nest $\left(F_{(3,}\right.$, $255)=365.62, p<0.05)$, c. is nest maximum temperature versus ambient maximum temperature for each nest $\left(F_{(3,}\right.$ $\left.{ }_{255}=186.22, p<0.05\right)$, and $d$. is nest minimum temperature versus ambient minimum temperature for each nest $\left(F_{(3,255)}=448.40, p<0.05\right)$. (Note: All values are mean+SE. All nests measured in the $2014-2015$ breeding season were active and successful.). 
Table 3. Nest and ambient temperature ranges $\left({ }^{\circ} \mathrm{C}\right)$ for southern ground-hornbill nests during the 2013-2014 and 2014-2015 breeding seasons.

\begin{tabular}{cccccc} 
& \multicolumn{2}{c}{ 2013-2014 season } & & \multicolumn{2}{c}{ 2014-2015 season } \\
\cline { 2 - 3 } \cline { 5 - 5 } Nest & $\begin{array}{c}\text { Cavity } \\
\text { temperatures }\end{array}$ & $\begin{array}{c}\text { Ambient } \\
\text { temperatures }\end{array}$ & & $\begin{array}{c}\text { Cavity } \\
\text { temperatures }\end{array}$ & $\begin{array}{c}\text { Ambient } \\
\text { temperatures }\end{array}$ \\
Hlahlene & $11.7-57.0$ & $12.2-58.6$ & & - & - \\
Jock & $17.7-36.1$ & $14.6-38.6$ & & $19.7-29.7$ & $15.7-42.2$ \\
Mangake & - & - & $17.1-32.6$ & $14.6-46.1$ \\
Mpfuleni & $11.1-33.1$ & $12.1-40.6$ & & - & - \\
Mudzadzene & $11.7-53.1$ & $11.6-53.5$ & & $16.2-40.2$ & $17.1-40.1$ \\
Nhlanganini & - & - & $17.2-10.2$ & - \\
Nwaswitsontso & $11.6-62.5$ & $11.1-52.6$ & & - & - \\
Oorlas & $5.6-45.1$ & $5.7-46.6$ & & - & - \\
PMC & $11.7-56.6$ & $11.6-42.1$ & & $13.7-54.6$ & $14.7-46.6$
\end{tabular}

Similarly, mean minimum and maximum nest cavity temperatures of southern groundhornbills differed significantly between the nests for both seasons (Figs. $3 \mathrm{~b}$ and $4 \mathrm{~b}$ ). The artificial nest maximum temperature was significantly warmer than nest minimum temperature in both breeding seasons (Post-hoc Scheffe, $p<0.05$ ). Maximum nest cavity temperatures of southern ground-hornbill nests differed significantly from maximum ambient temperatures for both breeding seasons (Figs. 3c and 4c). Ambient maximum temperature was higher than the nest maximum temperature for all nests excluding Mudzadzene nest (2014-2015 season), where the temperatures were almost equal, and the artificial nest (both seasons). The artificial nest maximum temperature was significantly higher than the maximum ambient temperature in both breeding seasons (Post-hoc Scheffe, $p<0.05)$. Similarly, minimum nest temperatures of southern ground-hornbill nests differed significantly to minimum ambient temperatures for both breeding seasons (Figs. $3 \mathrm{~d}$ and $4 \mathrm{~d}$ ). Generally, the nest minimum temperatures were warmer than the minimum ambient temperatures for all nests in both breeding seasons, with the exception of the artificial nest.

\section{Discussion}

Changes in local environmental conditions, in particular temperature, have been shown to affect birds in terms of the timing of egg laying (Both et al., 2004), timing of migration (Crick, 2004), nestling condition (Perez et al., 2008), and nest survival (Guerena et al., 2016). In savannas, the increase in ambient temperature as a result of increased $\mathrm{CO}_{2}$ concentrations, could incur significant vegetation changes (Buitenwerf et al., 2012) which could severely affect bird reproductive output. Southern ground-hornbills time their breeding to coincide with the first seasonal rainfall (Kemp and Kemp, 1991), which in the South African Lowveld occurs in late spring and early summer. Rainfall, is considered an influential factor in the breeding biology of southern ground-hornbills, as nesting only starts once the first rains of 
the wet season have fallen (Kemp and Kemp, 1991). This is most likely in response to the increased abundance of their typical prey (Kemp and Kemp, 1991). However, this also coincides with increased temperature during the daytime.

Climate change is expected to cause an overall increase in temperature and greater extremes in wet and dry seasons, as well as fluctuations in extreme temperatures (Thuiller et al., 2008). Our results showed a high plasticity and range in southern ground-hornbill nest cavity temperatures with some nests having stable nest temperatures both day and night, others decreased nest temperature at night, whereas others showed increased nest temperatures at night. This was interesting as we expected nest cavity temperatures to be more stable than ambient temperatures. We did, however, find that tree cavities provided a buffer against the maximum and minimum ambient temperatures for southern groundhornbills in the South African Lowveld, although the mean hourly nest cavity temperatures were generally warmer than the mean hourly ambient temperatures.

When comparing the ambient maximum and minimum temperatures to the nest maximum and minimum temperatures, the buffering effect of the natural tree cavities against the heat for southern ground-hornbills during incubation is evident. For the Mudzadzene nest in the 2014-2015 breeding season, the ambient and nest maximum and minimum temperatures were similar. This is the only natural nest in our study that is located in a dead snag, without a canopy. Not having adequate shade during the hottest part of the day or a canopy for cover at night could have affected these nest temperatures. The artificial nest was the only nest where the nest maximum was significantly higher than the ambient maximum across both breeding seasons. Similarly, there was a marked difference between the nest minimum and ambient minimum temperatures for the artificial nest across both seasons, with the artificial nest minimum being lower than ambient minimum. For the natural tree cavities, the nest minimum temperatures were higher than ambient minimum temperatures in both seasons.

Our results showed that the artificial nest, constructed from a 52 gallon plastic drum, provided little insulation against the extreme temperature fluctuations, day and night, experienced in the South African Lowveld. This nest was erected on privately-owned land by the land managers, as part of an experiment to see whether southern ground-hornbills would nest there. Surprisingly, this has been one of the most consistently successful nests (based on the number of seasons where nestlings reached ringing age) out of the 30-40 southern ground-hornbill nests that were monitored in this region over the past seven years. Nest cavity temperature maximums in the artificial nest (PMC) were $14.5^{\circ} \mathrm{C}$ and $8{ }^{\circ} \mathrm{C}$ higher than ambient temperature maximums for the 2013-2014 and 2014-2015 breeding seasons, respectively. These temperatures, however, were not the highest recorded nest cavity temperatures in the 2013-2014 breeding season, with two natural nests (Hlahlene (failed) and Nwaswitsontso (inactive)) reaching maximums above $56{ }^{\circ} \mathrm{C}$. These results are encouraging, as they suggest that southern ground-hornbills can breed successfully at extreme temperatures.

Many areas that would previously have supported southern ground-hornbills have been found unsuitable (Cilliers et al., 2013), limiting the potential range expansion of the species outside of protected areas. In an effort to enhance breeding, the use of artificial nest boxes 
for southern ground-hornbills has been implemented within areas of the Lowveld with great success (Wilson and Hockey, 2013). Much time and effort has been spent on determining the best design for a southern ground-hornbill artificial nest box to promote successful breeding. A workshop held in 2013 listed 10 points to consider when designing artificial nest boxes for southern ground-hornbills (Kemp et al., 2013). The dimensions of the cavity, entrance perches, roof structure and the attachment point were included, although the actual material used to construct the nest was not listed as a priority consideration (Kemp et al., 2013).

Although we only had one artificial nest site within our study area, our results suggest that groups will choose to use a sub-optimal nest in terms of ideal microclimate, if there is no suitable alternative nest within their territory. As a result of the fact that the group was able to nest successfully in these sub-optimal conditions, the dimensions of the nest cavity seem to be a more important factor than the construction material used for the nest for southern ground-hornbills. We would, however, still recommend constructing artificial nests out of natural materials, where possible, purely for the comfort of the birds and to better mimic the conditions (in particular the buffering effect) shown in natural tree cavities. Further research should investigate the effect of different nest box construction materials on nest microclimate towards providing southern ground-hornbills with high quality artificial nest sites at reintroduction sites.

\section{Acknowledgements}

We thank the Ford Wildlife Foundation and the First Rand Foundation (Project reference: 033391) for providing financial support for our research. This work was part of a registered research project with SANParks (POTTL988) that was approved by the relevant animal ethics committee. We thank SANParks for allowing access to the Kruger National Park and providing various GIS layers.

\section{References}

Bates, D., Maechler, M., Bolker, B., Walker, S., 2015. Fitting linear mixed-effects models using Ime4. J. Stat. Softw. 67, 1-48. http://dx.doi.org/10.18637/jss.v067.i01.

Both, C., Artemyev, A.V., Blaauw, B., Cowie, R.J., Dekhuijzen, A.J., Eeva, T., Enemar, A., Gustafsson, L., Ivankina, E.V., Järvinen, A., Metcalfe, N.B., et al., 2004. Large-scale geographical variation confirms that climate change causes birds to lay earlier. Proc. R. Soc. Lond. B. 271, 1657-1662.

Buitenwerf, R., Bond, W.J., Stevens, N., Trollope, W.S.W., 2012. Increased tree densities in South African savannas: > 50 years of data suggests $\mathrm{CO} 2$ as a driver. Glob. Change Biol. 18, 675-684.

Cilliers, D., Evans, S., Coetzee, H., Van Rensburg, L., 2013. Developing a site selection tool to assist reintroduction efforts for the southern ground-hornbill Bucorvus leadbeateri. Ostrich 84, 101-111. 
Cockle, K.L., Martin, K., Drever, M.C., 2010. Supply of tree-holes limits nest density of cavity-nesting birds in primary and logged subtropical Atlantic forest. Biol. Conserv. 143, 2851-2857.

Coombs, A.B., Bowman, J., Garroway, C.J., 2010. Thermal properties of tree cavities during winter in a northern hardwood forest. J. Wildl. Manag. 74, 1875-1881.

Cooper, S.J., 1999. The thermal and energetic significance of cavity roosting in mountain chickadees and juniper titmice. Condor 101, 863-866.

Crick, H.Q.P., 2004. The impact of climate change of birds. Ibis 146, 48-56. D'Alba, L., Monaghan, P., Nager, R.G., 2009. Thermal benefits of nest shelter for incubating female eiders. J. Therm. Biol. 34, 93-99.

Deeming, D.C., Mainwaring, M.C., Hartley, I.R., Reynolds, S.J., 2012. Local temperature and not latitude determines the design of blue tit and great tit nests. Avian Biol. Res. 5, 203-208.

DuRant, S.E., Hopkins, W.A., Hepp, G.R., Walters, J.R., 2013. Ecological, evolutionary, and conservation implications of incubation temperature-dependent phenotypes in birds. Biol. Rev. 88, 499-509.

Ellis, M.V., 2016. Influence of design on the microclimate in nest boxes exposed to direct sunshine. Aust. Zool. 38, 95-101.

Gertenbach, W.P.D., 1980. Rainfall patterns in the Kruger National Park. Koedoe 23, 35-43.

Gertenbach, W.P.D., 1983. Landscapes of the Kruger National Park. Koedoe 26, 9-122. Guerena, K.B., Castelli, P.M., Nichols, T.C., Willimas, C.K., 2016. Factors influencing nest survival in resident Canada geese. J. Wildl. Manag. 80, 1022-1030.

Hart, L.A., Downs, C.T., Brown, M., 2016. Sitting in the sun: nest microhabitat affects incubation temperatures in seabirds. J. Therm. Biol. 60, 149-154.

Heenan, C.B., 2013. An overview of the factors influencing the morphology and thermal properties of avian nests. Avian Biol. Res. 6, 104-118.

Hilton, G.M., Hansell, M.H., Ruxton, G.D., Reid, J.M., Monaghan, P., 2004. Using artificial nests to test importance of nesting material and nest shelter for incubation energetics. Auk 121, 777-787.

Hooge, P.N., Stanback, M.T., Koenig, W.D., 1999. Nest-site selection in the Acorn Woodpecker. Auk 116, 4554.

Jordan, M. (Ed)., 2011. Southern ground hornbill (Bucorvus leadbeateri) species recovery plan for South Africa. Conservation Breeding Specialist Group (SSC/IUCN)/CBSG South Africa/Johannesburg Zoo/Endangered Wildlife Trust, Johannesburg.

Kemp, A.C., 1995. The Hornbills: Bucerotiformes. Oxford University Press, Oxford, UK.

Kemp, A.C., Kemp, L.V., Nienaber, N., Weprin, N.E., 2013. Use of artificial nest cavities in southern groundhornbill conservation: preparing a national strategy. Mabula Ground Hornbill Project, Limpopo.

Kemp, A.C., Kemp, M.I., 1991. Timing of egg laying by southern ground-hornbill Bucorvus leadbeateri in the Kruger National Park, South Africa, and conservation implications. Ostrich 67, 9-14.

Kemp A.C., Webster R., 2008. Latest analysis of southern ground hornbill (SGH) distribution and population in South Africa: December 2008. Unpublished manuscript. 
Kemp, S., Monaghan, P., 2006. Effects of early incubation constancy on embryonic development: an experimental study in the herring gull Larus argentatus. J. Therm. Biol. 31, 416-421.

Martin, T.E., Ghalambor, C.K., 1999. Males feeding females during incubation. I. Required by microclimate or constrained by nest predation? Am. Nat. 153, 131-139.

Matthysen, E., Adriaensen, F., Dhondt, A.A., 2011. Multiple responses to increasing spring temperatures in the breeding cycle of blue and great tits (Cyanistes caeruleus, Parus major). Glob. Change Biol. 17, 1-16.

Maziarz, M., Broughton, R.K., Wesolowski, T., 2017. Microclimate in tree cavities and nest-boxes: implications for hole-nesting birds. For. Ecol. Manag. 389, 306-313.

Newton, I., 1994. The role of nest sites in limiting the numbers of hole-nesting birds: a review. Biol. Conserv. 70, 265-276.

Perez, J.H., Ardia, D.R., Chad, E.K., Clotfelter, E.D., 2008. Experimental heating reveals nest temperature affects nestling condition in tree swallows (Tachycineta bicolor). Biol. Lett. 4, 468-471.

R Core Team, 2016. R: A language and environment for statistical computing. R Foundation for Statistical Computing, Vienna, Austria. URL 〈https://www.R-project. org/〉.

Reid, J.M., Monaghan, P., Ruxton, G.D., 2000. Resource allocation between reproductive phases: the importance of thermal conditions in determining the cost of incubation. Proc. R. Soc. Lond. B 267, 37-41.

Robertson, R.J., Rendell, W.B., 1990. A comparison of the breeding ecology of a secondary cavity nesting bird, the tree swallow (Tachycineta bicolor), in nest boxes and natural cavities. Can. J. Zool. 68, 1046-1052.

Taylor, M.R., Peacock, F., Wanless, R.M., 2015. The Eskom Red Data Book of birds of South Africa, Lesotho and SwazilandBirdLife South Africa. Johannesburg.

The IUCN Red List of Threatened Species. Version 2016-1. 〈www.iucnredlist.org〉 Downloaded on 06 July 2016.

Thuiller, W., Richardson, D.M., Midgley, G.F., 2008. Will climate change promote alien plant invasions? In: Nentwig, W. (Ed.), Biological Invasions. Springer Berlin Heidelberg, 197-211.

Wickham, H., 2009. ggplot2: Elegant Graphics for Data Analysis. Springer-Verlag, New York.

Wiebe, K.L., 2001. Microclimate of tree cavity nests: is it important for reproductive success in northern flickers? Auk 118, 412-421.

Wilke, C.O., 2016. Cowplot: Streamlined Plot Theme and Plot Annotations for 'ggplot2'. R package version 0.6.2. URL 〈https://CRAN.R-project.org/package=cowplot $\rangle$.

Wilson, G., Hockey, P.A.R., 2013. Causes of variable reproductive performance by southern ground-hornbill Bucorvus leadbeateri and implications for management. Ibis 155, 476-484. 